\title{
Seleksi Segregan Gandum (Triticum aestivum L.) pada Dataran Tinggi
}

\section{Selection of Wheat (Triticum aestivum L.) Segregant on High Altitude Conditions}

\author{
Sri Wardani ${ }^{1}$, Desta Wirnas ${ }^{2 *}$, dan Yudiwanti Wahyu ${ }^{2}$ \\ ${ }^{1}$ Program Studi Pemuliaan dan Bioteknologi Tanaman, Sekolah Pascasarjana, Institut Pertanian Bogor \\ ${ }^{2}$ Departemen Agronomi dan Hortikultura, Fakultas Pertanian, Institut Pertanian Bogor \\ (Bogor Agricultural University), Jl. Meranti, Kampus IPB, Darmaga, Bogor 16680, Indonesia
}

Diterima 11 Juli 2014/Disetujui 12 November 2014

\begin{abstract}
Pedigree selection is a method of selection used in segregating populations which takes the expertise of breeders in achieving the desired goal. This method is implemented on the early generations with a high degree of segregation and is generally performed on highly heritable traits. The purpose of this research was to study the performance of F3 generation segregants and to estimate the genetic parameters to be used for identification and selection of wheat segregants under optimum environmental condition. The research was carried out at the experiment field of Research Institute for Ornamental Crops, in Cipanas from May to September 2012. Genetic material used were 58 F3 family and six check varieties, namely Dewata, Selayar, Oasis, Rabe, Basribey, and HP 1744. The experiment used an augmented design. Results of analysis of variance showed that the family effect was significant for days to flowering, days to harvest, percentage of empty florets, number of grains per panicle, grain weight per panicle, number of seeds per plant and seed weight per plant. High heritability estimates were found in days to flowering, days to harvest, seed filling period, percentage of empty florets, number of grains per panicle, grain weight per panicle, number of seeds per plant, and seed weight per plant. These characters are suitable for yield improvement of tropical highland wheat due to its high heritability values. The mean value of F3 generation changes subsequent to selection either based on grain weight per plant, or based on number of productive tillers, number of grain per panicle, and grain weight per plant.
\end{abstract}

Keywords: selection criteria, segregation, tropical, yield

\section{ABSTRAK}

Seleksi pedigree merupakan metode seleksi yang digunakan pada populasi bersegregasi, yang membutuhkan keahlian dari pemulia dalam mencapai tujuan yang diinginkan. Metode seleksi ini dilakukan pada generasi awal dengan tingkat segregasi tinggi dan umumnya dilakukan pada karakter yang memiliki nilai heritabilitas tinggi. Tujuan penelitian ini adalah memperoleh informasi tentang keragaan segregan gandum generasi F3 serta menduga nilai parameter genetiknya sebagai informasi untuk mengidentifikasi dan menyeleksi segregan gandum di lingkungan optimum. Penelitian ini dilaksanakan di kebun Percobaan Balithi, Cipanas mulai bulan Mei sampai September 2012. Materi genetik yang digunakan adalah 58 famili F3 dan enam varietas pembanding, yaitu Dewata, Selayar, Oasis, Rabe, Basribey, dan HP 1744. Rancangan percobaan yang digunakan adalah rancangan perbesaran (augmented design). Hasil analisis ragam menunjukkan bahwa famili berbeda nyata pada karakter umur berbunga, umur panen, periode pengisian biji, persentase floret hampa, jumlah biji per malai, bobot biji per malai, jumlah biji per tanaman, dan bobot biji per tanaman. Nilai duga heritabilitas tinggi terdapat pada karakter umur berbunga, umur panen, persentase floret hampa, jumlah biji per malai, bobot biji per malai, jumlah biji per tanaman, dan bobot biji per tanaman. Karakter ini dapat digunakan sebagai karakter seleksi untuk peningkatan hasil gandum pada dataran tinggi daerah tropika karena memiliki nilai heritabilitas tinggi. Populasi gandum generasi F3 memiliki perubahan nilai tengah setelah dilakukannya seleksi, baik seleksi berdasarkan karakter bobot biji per tanaman, maupun seleksi berdasarkan karakter jumlah anakan produktif, jumlah biji per malai, dan bobot biji per tanaman.

Kata kunci: kriteria seleksi, segregasi, tropika, hasil

\footnotetext{
* Penulis untuk korespondensi. e-mail: desta.wirnas@yahoo.com
} 


\section{PENDAHULUAN}

Peranan gandum sebagai pendukung ketahanan pangan dunia secara global mengakibatkan tanaman gandum telah menjadi salah satu komoditi pangan yang penting. Saat ini Indonesia telah menjadi negara pengimpor gandum terbesar sehingga mengakibatkan peningkatan pengeluaran devisa negara. Oleh karena itu, usaha untuk memproduksi gandum sangat perlu dilakukan untuk mengurangi volume impor gandum. Usaha memproduksi gandum perlu didukung oleh ketersediaan varietas yang sesuai dengan kondisi agroklimat di Indonesia (Budiarti, 2005; Setyowati et al., 2009).

Gandum dapat tumbuh baik pada kondisi curah hujan sekitar 40-60 $\mathrm{cm}$ per tahun. Berdasarkan musim produksi tanaman gandum terdiri dari 2 jenis, yaitu gandum musim dingin (winter wheat) dan gandum musim semi (spring wheat) (Acquaah, 2007). Gandum musim dingin adalah gandum yang mampu bertahan pada suhu dingin di bawah $40{ }^{\circ} \mathrm{C}$ jika dilindungi salju, pertumbuhannya berhenti dan mengalami dormansi selama musim dingin, kemudian melanjutkan pertumbuhan di musim semi untuk panen di musim panas. Gandum musim semi merupakan tanaman berhari panjang dan kurang toleran pada suhu rendah dan mengalami kerusakan pada suhu sekitar $2-1{ }^{\circ} \mathrm{C}$ (Acquaah, 2007).

Gandum merupakan salah satu tanaman serealia yang berasal dari daerah subtropis. Pengembangan gandum di Indonesia berdasarkan hasil penelitian menunjukkan bahwa gandum dapat ditanam daerah dataran tinggi dengan ketinggian tempat mencapai $>1,000 \mathrm{~m}$ dpl yang memiliki iklim hampir sama dengan lingkungan subtropik (Nur et al., 2012). Penanaman gandum di daerah tropik perlu didukung oleh ketersediaan varietas yang adaptif. Saat ini baru beberapa varietas gandum yang sudah dilepas untuk kondisi tropik sehingga pengembangan varietas gandum yang sesuai untuk kondisi tropik masih perlu dilakukan.

Sebagai upaya untuk mengembangkan varietas gandum, maka telah diperoleh sejumlah individu generasi F2 yang diseleksi dengan metode pedigree (Natawijaya, 2012). Individu-individu terseleksi dari generasi F2 merupakan segregan yang kemudian ditanam menjadi famili-famili F3. Tujuan penelitian ini adalah memperoleh informasi tentang keragaan segregan F3 serta menduga nilai parameter genetiknya sebagai informasi untuk mengidentifikasi dan menyeleksi segregan gandum di lingkungan optimum (dataran tinggi).

\section{BAHAN DAN METODE}

Percobaan ini dilaksanakan mulai bulan Mei sampai dengan September 2012 di kebun percobaan BalithiCipanas yang terletak pada ketinggian tempat $1,100 \mathrm{~m} \mathrm{dpl}$. Materi genetik yang digunakan adalah 58 famili F3 dan 2 varietas pembanding, yaitu Dewata dan Selayar sebagai varietas nasional, serta 4 galur introduksi, yaitu Oasis, Rabe, Basribey, dan HP 1744.

Percobaan ini disusun dengan rancangan perbesaran (augmented design). Unit percobaan merupakan petakan berukuran $1 \mathrm{~m}$ x $1 \mathrm{~m}$. Benih ditanam dengan cara tugal pada jarak tanam $10 \mathrm{~cm}$ x $10 \mathrm{~cm}$. Masing-masing famili ditanam sebanyak 60 benih per satuan percobaan. Jumlah tanaman contoh yang diamati adalah 30 tanaman per petak. Keenam pembanding terdiri atas 2 varietas nasional (Dewata dan Selayar) dan 4 galur (Oasis, Rabe, Basribey, dan HP 1744) ditanam dalam petak dengan ukuran yang sama dan diulang sebanyak 4 kali.

Pemupukan pertama diberikan pada umur 10 hari setelah tanam dengan dosis per hektar sebanyak $150 \mathrm{~kg}$ Urea, $100 \mathrm{~kg} \mathrm{SP36,100} \mathrm{kg} \mathrm{KCl} \mathrm{dan} \mathrm{pemupukan} \mathrm{ke} \mathrm{dua}$ pada umur 30 hari setelah tanam dengan dosis sebanyak 150 kg Urea. Pemeliharaan tanaman dilakukan sesuai dengan kebutuhan tanaman di lapang. Pemanenan dilakukan pada saat malai telah mengering yang ditandai dengan $95 \%$ malai telah berubah warna menjadi kecoklat-coklatan pada setiap individunya.

Pengamatan dilakukan terhadap karakter tinggi tanaman $(\mathrm{cm})$, jumlah anakan, jumlah anakan produktif, panjang malai (cm), jumlah spikelet, umur berbunga (HST), umur panen (HST), periode pengisian biji, jumlah floret total, jumlah floret hampa, persentase floret hampa (\%), jumlah biji per malai, bobot biji per malai (g), jumlah biji per tanaman, dan bobot biji per tanaman $(\mathrm{g})$.

Analisis ragam (ANOVA) dilakukan menggunakan software SAS 9.1.3. Pendugaan ragam antar check menggunakan uji F pada taraf 5\%, dan uji lanjut Duncan's Multiple Range Test (DMRT) dilakukan bila terdapat pengaruh yang nyata. Pendugaan nilai heritabilitas arti luas $\left(\mathrm{h}^{2}{ }_{\text {bs }}\right)$ dilakukan berdasarkan pemisahan nilai kuadrat tengah harapan famili $\left(\sigma_{\mathrm{g}}^{2}\right)$ terhadap keragaman fenotipe $\left(\sigma_{\mathrm{p}}^{2}\right)$ dengan kriteria : $\mathrm{h}^{2}{ }_{\mathrm{bs}}>50 \%$ (tinggi), $20 \%<\mathrm{h}^{2}{ }_{\mathrm{bs}} \leq 50 \%$ (sedang), dan $\mathrm{h}^{2}{ }_{\mathrm{bs}} \leq 20 \%$ (rendah); kemudian dilanjutkan untuk menghitung nilai diferensial seleksi. Nilai heritabilitas dan koefisien keragaman genetik (KKG) dihitung dengan persamaan : $\sigma_{\mathrm{e}}^{2}=\mathrm{KT} / \mathrm{r} ; \sigma_{\mathrm{g}}^{2}=\left(\mathrm{KT}_{\mathrm{g}}-\mathrm{KT}_{\mathrm{e}}\right) / \mathrm{r} ; \sigma_{\mathrm{p}}^{2}=\sigma_{\mathrm{g}}^{2}+\sigma_{\mathrm{e}}^{2}$; $\mathrm{KKG}=\left(\left(\sigma_{\mathrm{g}} / \overline{\mathrm{x}}\right)^{\mathrm{e}} \times 100\right)$; dengan $\mathrm{KT}_{\mathrm{e}}^{\mathrm{g}}=$ kuadrat tengah galat; $\mathrm{KT}_{\mathrm{g}}=$ kuadrat tengah famili; $\mathrm{r}=$ ulangan; $\sigma_{\mathrm{g}}=$ simpangan baku; $\overline{\mathrm{x}}=$ nilai tengah seluruh famili (Syukur et al., 2010).

Nilai keragaman genetik suatu karakter ditentukan berdasarkan ragam famili dan standar deviasi ragam famili menurut rumus berikut:

$\sigma \sigma_{g}^{2}=\sqrt{2} / r^{2}\left[\left(\frac{K T g^{2}}{d b_{g}+2}\right)+\left(\frac{K T e^{2}}{d b_{e}+2}\right)\right]$

dimana, $\mathrm{KT}_{\mathrm{e}}=$ kuadrat tengah galat; $\mathrm{KT}_{\mathrm{g}}=$ kuadrat tengah famili; $\mathrm{r}=$ ulangan; $\mathrm{db}_{\mathrm{g}}=$ derajat bebas famili; $\mathrm{db}_{\mathrm{e}}=$ derajat bebas galat. Apabila $\sigma_{\mathrm{g}}^{2}>\sigma_{\sigma 2 \mathrm{~g}}$ : keragaman familinya luas, sedangkan $\sigma_{\mathrm{g}}^{2}<\sigma_{\sigma 2 \mathrm{~g}}$ : keragaman familinya sempit (Prinaria et al., 1995).

Seleksi famili-famili terbaik dilakukan berdasarkan karakter komponen hasil atau hasil, lalu dilanjutkan dengan seleksi individu terbaik dari famili terbaik.

\section{HASIL DAN PEMBAHASAN}

Materi genetik yang diuji dalam penelitian ini terdiri atas varietas nasional dan galur introduksi sebagai 
pembanding, serta populasi F3 yang diperoleh dari persilangan antara varietas nasional (Selayar) dan galur introduksi (Rabe). Populasi F3 ditanam menjadi famili gandum yang merupakan hasil seleksi generasi F2 dari persilangan antara kedua tetua. Berdasarkan hasil uji t pada taraf 5\% diketahui bahwa varietas nasional (Selayar) dan galur introduksi (Rabe) memiliki keragaan yang berbeda nyata hanya pada karakter persentase floret hampa (Tabel 1). Berdasarkan hasil pengujian Balitsereal (2011) diketahui bahwa kedua tetua yang digunakan merupakan varietas yang rekomendasikan untuk wilayah dataran tinggi.

Berdasarkan hasil analisis ragam diketahui bahwa genotipe dan famili berbeda nyata pada karakter umur berbunga, umur panen, periode pengisian biji, persentase floret hampa, jumlah biji per malai, bobot biji per malai, jumlah biji per tanaman, dan bobot biji per tanaman, sedangkan check merupakan varietas nasional dan galur introduksi yang digunakan untuk membandingkan dengan famili F3 hanya nyata untuk tinggi tanaman (Tabel 2). Hal ini menunjukkan bahwa terdapat keragaman antar genotipe dan antar famili pada karakter umur berbunga, umur panen, persentase floret hampa, jumlah biji per malai, bobot biji per malai, jumlah biji per tanaman, dan bobot biji per tanaman di antara famili yang diuji.

Nur et al. (2012) melaporkan bahwa terdapat perbedaan keragaan karakter umur berbunga, umur panen, persentase floret hampa, jumlah biji dan bobot biji per malai pada berbagai genotipe gandum yang ditanam di lokasi berelevasi rendah dan elevasi tinggi (Cipanas dan Bogor). Berdasarkan hasil penelitian Wirawan et al. (2013) diketahui bahwa varietas berpengaruh nyata terhadap tinggi tanaman, panjang malai, jumlah anakan produktif, umur berbunga, umur panen, jumlah spiklet per malai, jumlah biji per malai, bobot 1,000 biji, dan produksi gandum yang ditanam pada ketinggian \pm 1390 meter di atas permukaan laut. Hal ini juga didukung oleh hasil penelitian Mangi et al. (2007) yang menunjukkan bahwa terdapat perbedaan keragaan genotipe gandum untuk karakter jumlah biji per malai dan bobot biji per tanaman pada lokasi dataran tinggi. Wahyu et al. (2013) melaporkan bahwa umur berbunga dan umur panen gandum memiliki keragaman ketika ditanam pada kondisi tropik.

Hasil pengamatan pada famili generasi F3 menunjukkan bahwa nilai tengah populasi F3 untuk karakter tinggi tanaman, panjang malai, dan persentase floret hampa berada di antara nilai tengah kedua tetua. Karakter jumlah spikelet, umur berbunga, umur panen, jumlah floret total, jumlah floret hampa, dan jumlah biji per malai memiliki nilai tengah lebih tinggi dibandingkan dengan kedua tetuanya. Nilai pengamatan pada famili F3 memiliki kisaran yang luas, yaitu terdapat famili yang memiliki nilai lebih tinggi atau lebih rendah dibandingkan kedua tetua. Hal ini memberikan peluang untuk memilih famili terbaik dan individu terbaik dari famili terbaik dari populasi yang digunakan.

Berdasarkan hasil uji DMRT pada taraf 5\% diketahui bahwa varietas Selayar dan Dewata memiliki tinggi tanaman yang berbeda nyata dengan varietas Oasis, Rabe, Basribey dan HP 1744. Varietas HP 1744 memiliki umur berbunga paling panjang dan berbeda nyata dengan pembanding lainnya (Tabel 3). Nur et al. (2012) melaporkan bahwa genotipe HP 1744 memiliki kecenderungan lebih genjah dibanding varietas Selayar dan Rabe di dataran rendah, sedangkan di dataran tinggi genotipe yang memiliki umur berbunga lebih genjah adalah Rabe.

Menurut Budiarti (2005), klasifikasi tinggi tanaman gandum yaitu kelompok pendek (53.5-65.2 cm), kelompok

Tabel 1. Keragaan karakter agronomi famili-famili F3 gandum hasil persilangan antara varietas Selayar x Rabe di dataran tinggi

\begin{tabular}{lccccc}
\hline Karakter & Selayar & Rabe & thitung & Populasi F3 & Kisaran famili F3 \\
\hline Tinggi tanaman (cm) & 74.5 & 62.8 & 19.9 & 67.8 & $41.0-88.8$ \\
Jumlah anakan & 5.8 & 5.7 & 1.4 & 5.6 & $2.8-7.8$ \\
Jumlah anakan produktif & 5.4 & 5.5 & 1.3 & 5.4 & $2.8-7.6$ \\
Panjang malai (cm) & 9.5 & 8.8 & 2.3 & 9.0 & $7.4-10.5$ \\
Jumlah spiklet & 15.5 & 15.9 & 2.6 & 17.8 & $14.3-20.0$ \\
Umur berbunga (HST) & 61.5 & 59.8 & 2.9 & 61.3 & $55.0-66.6$ \\
Umur panen (HST) & 95.8 & 96.4 & 7.5 & 96.8 & $86.9-109.8$ \\
Periode pengisian biji & 34.3 & 36.5 & 5.9 & 35.5 & $29.2-47.2$ \\
Jumlah floret total & 46.6 & 47.6 & 7.9 & 53.4 & $43.0-60.1$ \\
Jumlah floret hampa & 30.2 & 32.9 & 4.6 & 35.8 & $7.4-48.6$ \\
Persentase floret hampa (\%) & 64.7 & 69.1 & $1.2 *$ & 67.1 & $14.9-87.9$ \\
Jumlah biji per malai & 16.4 & 14.6 & 3.5 & 17.5 & $6.4-45.5$ \\
Bobot biji per malai (g) & 0.4 & 0.3 & 0.2 & 0.4 & $0.2-1.7$ \\
Jumlah biji per tanaman & 188.9 & 172.8 & 26.5 & 132 & $57.9-184.6$ \\
Bobot biji per tanaman $(\mathrm{g})$ & 5.2 & 4.5 & 1.8 & 3.7 & $1.7-5.3$ \\
\hline
\end{tabular}

keterangan: *= berbeda nyata pada taraf $5 \%$ berdasarkan uji t 
Tabel 2. Kuadrat tengah karakter morfologis, komponen hasil, dan hasil gandum di dataran tinggi

\begin{tabular}{|c|c|c|c|c|c|c|}
\hline \multirow{2}{*}{ Karakter } & \multicolumn{6}{|c|}{ Sumber keragaman } \\
\hline & Genotipe $(\mathrm{G})$ & $\operatorname{Pr}>f$ & Famili (F) & $\operatorname{Pr}>f$ & G vs F & $\operatorname{Pr}>f$ \\
\hline Tinggi tanaman & 80.6 & 0.2646 & 58.7 & 0.5476 & $330.9^{*}$ & 0.004 \\
\hline Jumlah anakan & 0.8 & 0.3721 & 0.7 & 0.4344 & 1.5 & 0.103 \\
\hline Jumlah anakan produktif & 0.8 & 0.3201 & 0.7 & 0.3597 & 1.3 & 0.119 \\
\hline Panjang malai & 0.5 & 0.7158 & 0.5 & 0.7446 & 0.8 & 0.339 \\
\hline Jumlah spiklet & 2.1 & 0.4871 & 1.8 & 0.6435 & 2.5 & 0.346 \\
\hline Umur berbunga & $8.9 *$ & 0.0144 & $8.8^{*}$ & 0.0154 & $11.0 *$ & 0.027 \\
\hline Umur panen & 15.8 & 0.0616 & $16.7 *$ & 0.0497 & 4.8 & 0.681 \\
\hline Periode pengisian biji & $22.5 * *$ & 0.0003 & $24.2 * *$ & 0.0002 & 6.2 & 0.229 \\
\hline Jumlah floret total & 19.3 & 0.4871 & 16.4 & 0.6435 & 22.5 & 0.346 \\
\hline Jumlah floret hampa & 34.1 & 0.1207 & 34.6 & 0.1158 & 21.1 & 0.415 \\
\hline Persentase floret hampa & $85.4 * *$ & 0.0010 & $93.0 * *$ & 0.0016 & 14.8 & 0.561 \\
\hline Jumlah biji per malai & $25.3 * *$ & $<.0001$ & $27.3 * *$ & $<.0001$ & 2.8 & 0.491 \\
\hline Bobot biji per malai & $0.03 * *$ & $<.0001$ & $0.04 * *$ & $<.0001$ & 0.0 & 0.426 \\
\hline Jumlah biji per tanaman & $1191.4^{* *}$ & $<.0001$ & $514.9 * *$ & 0.0011 & 202.9 & 0.175 \\
\hline Bobot biji per tanaman & $1.0^{*}$ & 0.0077 & $0.7^{*}$ & 0.0440 & 0.5 & 0.191 \\
\hline
\end{tabular}

Keterangan: * berpengaruh nyata pada taraf $5 \% ; * *=$ berpengaruh nyata pada taraf $1 \%$

sedang (>65.2-76.9 cm) dan kelompok tinggi $(>76.9$ $\mathrm{cm})$. Berdasarkan nilai rataan diketahui bahwa tidak ada tanaman gandum yang temasuk dalam kategori kelompok tinggi. Tanaman gandum yang termasuk kelompok pendek sebanyak 4 varietas, sedangkan 2 varietas lainnya tergolong pada kelompok tinggi tanaman yang sedang. Tabel 3, menunjukkan umur panen 6 varietas pembanding dan umumnya tanaman gandum yang memiliki umur berbunga lebih cepat maka akan mempunyai umur panen yang cepat pula. Data rataan umur panen yang dimiliki pada setiap varietas menunjukkan bahwa varietas Basribey memiliki umur berbunga dan panen yang lebih cepat dibandingkan varietas pembanding lainnya. Hasil ini sesuai dengan penelitian Natawijaya (2012), bahwa varietas Basribey memiliki umur panen yang lebih awal dibandingkan dengan varietas lainnya.

Tabel 3. Keragaan varietas pembanding gandum di dataran tinggi

\begin{tabular}{|c|c|c|c|c|c|c|}
\hline Karakter & Dewata & Selayar & Oasis & Rabe & Basribey & HP 1744 \\
\hline Tinggi tanaman $(\mathrm{cm})$ & $74.2 \mathrm{a}$ & $74.5 \mathrm{a}$ & $59.3 b$ & $62.8 \mathrm{ab}$ & $51.4 b$ & $59.9 \mathrm{~b}$ \\
\hline Jumlah anakan & 5.5 & 5.8 & 5.3 & 5.7 & 6.5 & 4.6 \\
\hline Jumlah anakan produktif & 5.3 & 5.4 & 5.2 & 5.5 & 6.3 & 4.5 \\
\hline Panjang malai (cm) & 9.6 & 9.5 & 9.0 & 8.8 & 8.7 & 8.6 \\
\hline Jumlah spiklet & 17.8 & 15.5 & 16.8 & 15.9 & 16.6 & 16.2 \\
\hline Umur berbunga (HST) & $59.5 b$ & $61.5 \mathrm{ab}$ & $61.4 \mathrm{ab}$ & $59.8 b$ & $59.0 \mathrm{~b}$ & $63.4 \mathrm{a}$ \\
\hline Umur panen (HST) & 95.7 & 95.8 & 95.1 & 96.4 & 93.9 & 97.1 \\
\hline Periode pengisian biji & 36.2 & 34.3 & 33.6 & 36.5 & 35.0 & 33.7 \\
\hline Jumlah floret total & 53.3 & 46.6 & 50.4 & 47.6 & 49.7 & 48.6 \\
\hline Jumlah floret hampa & 36.7 & 30.2 & 35.5 & 32.9 & 34.3 & 32.5 \\
\hline Persentase floret hampa (\%) & 68.5 & 64.7 & 70.2 & 69.1 & 68.0 & 66.9 \\
\hline Jumlah biji per malai & 16.7 & 16.4 & 14.9 & 14.6 & 15.3 & 16.1 \\
\hline Bobot biji per malai (g) & 0.4 & 0.4 & 0.4 & 0.3 & 0.4 & 0.4 \\
\hline Jumlah biji per tanaman & 180.9 & 188.9 & 188.4 & 172.8 & 176.3 & 173.8 \\
\hline Bobot biji per tanaman (g) & 4.8 & 5.2 & 4.9 & 4.5 & 4.3 & 4.4 \\
\hline
\end{tabular}

Keterangan: Angka yang diikuti oleh huruf yang berbeda pada baris yang sama berbeda nyata berdasarkan uji DMRT pada taraf 5\% 
Keragaman pada famili F3 dapat disebabkan oleh faktor genetik dan lingkungan. Agar seleksi dapat memberikan kemajuan genetik yang diharapkan maka harus ditentukan terlebih dahulu karakter seleksi yang sesuai. Karakter seleksi untuk suatu populasi pada lingkungan tertentu dipilih berdasarkan nilai heritabilitas. Karakter yang dapat digunakan untuk menyeleksi genotipe harapan adalah karakter yang memiliki kriteria heritabilitas tinggi dan ragam heritabilitas rendah.

Nilai heritabilitas tergantung pada ragam genotipe dan ragam lingkungan. Heritabilitas adalah proporsi ragam yang disebabkan oleh faktor genetik terhadap ragam fenotipe. Dalam penelitian ini nilai heritabilitas arti luas hanya diduga pada karakter yang menunjukkan perbedaan nilai tengah antar famili pada analisis ragam. Nilai heritabilitas karakter diperoleh berkisar antara 0.0-0.9 (Tabel 4) yang berarti bahwa terdapat keragaman fenotipe yang tidak dipengaruhi oleh faktor genetik, namun terdapat juga karakter yang sangat dipengaruhi faktor genetik.

Penerapan metode seleksi berdasarkan nilai heritabilitas tinggi dapat dilakukan dengan menggunakan metode seleksi pedigree. Seleksi dilakukan pada generasi awal dengan menggunakan karakter-karakter terpilih berdasarkan nilai heritabilitas tinggi. Jika dalam populasi F3 memiliki nilai heritabilitas rendah, maka metode seleksi yang sesuai digunakan adalah metode seleksi bulk (Syukur et al., 2012).

Nilai heritabilitas merupakan salah satu parameter genetik yang dipertimbangkan untuk memilih karakter seleksi (Wirnas et al., 2006; Suharsono dan Jusuf, 2009; Sungkono et al., 2009; Syukur et al., 2010; Yunianti et al., 2010; Barmawi et al., 2013). Berdasarkan nilai heritabilitas tinggi maka karakter yang dapat dipertimbangkan sebagai karakter seleksi untuk menyeleksi famili terbaik adalah umur panen, persentase floret hampa, jumlah dan bobot biji per malai, serta jumlah dan bobot biji per tanaman.

Tujuan seleksi sebagai dasar untuk memperbaiki tanaman dalam memperoleh varietas unggul baru. Peranan keragaman genetik pada perakitan varietas unggul sangat penting karena tingginya keragaman genetik memberikan peluang untuk mendapatkan sumber gen bagi karakter yang akan diperbaiki (Martono, 2009). Nilai koefisien genetik berkisar antara 0.0-23.7\% (Tabel 4). Berdasarkan Yunianti et al. (2010) menyatakan bahwa tingginya nilai koefisien genetik pada umumnya diikuti dengan nilai heritabilitas dan ragam genetik yang tinggi, sehingga hal ini dapat dimanfaatkan untuk dilakukannya seleksi.

Hasil penelitian ini menunjukkan bahwa umur panen memiliki keragaman genetik yang ditunjukkan oleh nilai heritabilitas yang tergolong tinggi. Diharapkan dengan memilih genotipe yang berumur panjang akan diperoleh genotipe dengan periode pengisian biji yang lebih panjang. Hal ini didukung oleh hasil penelitian Nur et al. (2012) dan Natawijaya (2012) yang menunjukkan bahwa karakter umur panen merupakan salah satu karakter yang memiliki nilai heritabilitas tinggi sehingga karakter ini dapat dijadikan sebagai karakter seleksi pada generasi awal dalam proses perakitan varietas.

Metode seleksi pedigree digunakan dalam penelitian ini. Pemilihan karakter yang menjadi tujuan seleksi dapat dilakukan melalui karakter tunggal dan beberapa karakter sekaligus (multikarakter). Seleksi tunggal merupakan seleksi yang dilakukan hanya pada satu karakter saja, yaitu karakter bobot biji per tanaman dengan tujuan memperoleh famili -

Tabel 4. Nilai ragam genotipe, standar deviasi, koefisien keragaman genetik, ragam fenotipe, dan heritabilitas arti luas karakter agronomi famili-famili F3 gandum pada dataran tinggi

\begin{tabular}{|c|c|c|c|c|c|}
\hline Karakter & $\sigma_{g}^{2}$ & $2\left(\sigma_{\sigma 2 \mathrm{~g}}\right)$ & $\mathrm{KKG}$ & $\sigma_{p}^{2}$ & $\mathrm{~h}_{\text {bs }}^{2}$ \\
\hline Tinggi tanaman & 0.0 & 11.6 (sempit) & 0.0 & 14.7 & 0.0 (rendah) \\
\hline Jumlah anakan & 0.02 & 0.1 (sempit) & 2.4 & 0.2 & 0.1 (rendah) \\
\hline Jumlah anakan produktif & 0.03 & 0.1 (sempit) & 3.2 & 0.2 & 0.2 (sedang) \\
\hline Panjang malai & 0.0 & 0.1 (sempit) & 0.0 & 0.1 & 0.0 (rendah) \\
\hline Jumlah spiklet & 0.0 & 0.4 (sempit) & 0.0 & 0.5 & 0.0 (rendah) \\
\hline Umur berbunga & 1.4 & 1.0 (luas) & 1.9 & 2.2 & 0.6 (tinggi) \\
\hline Umur panen & 2.3 & 2.0 (luas) & 1.5 & 4.2 & 0.5 (tinggi) \\
\hline Periode pengisian biji & 5.1 & 2.3 (luas) & 6.3 & 6.1 & 0.8 (tinggi) \\
\hline Jumlah floret total & 0.0 & 3.5 (sempit) & 0.0 & 4.1 & 0.0 (rendah) \\
\hline Jumlah floret hampa & 3.7 & 4.7 (sempit) & 5.4 & 8.7 & 0.4 (sedang) \\
\hline Persentase floret hampa & 18.7 & 9.1 (luas) & 6.4 & 23.3 & 0.8 (tinggi) \\
\hline Jumlah biji per malai & 6.1 & 2.6 (luas) & 14.0 & 6.8 & 0.9 (tinggi) \\
\hline Bobot biji per malai & 0.007 & $3 \times 10^{-3}$ (luas) & 23.7 & 0.008 & 0.9 (tinggi) \\
\hline Jumlah biji per tanaman & 100.4 & 51.2 (luas) & 7.6 & 128.7 & 0.8 (tinggi) \\
\hline Bobot biji per tanaman & 0.1 & 0.1 (luas) & 8.1 & 0.2 & 0.6 (tinggi) \\
\hline
\end{tabular}

Keterangan: $\sigma^{2} \mathrm{~g}=$ ragam genotipe; $\sigma^{2} \mathrm{p}=$ ragam fenotipe; $\mathrm{h}_{\mathrm{bs}}^{2}=$ heritabilitas arti luas; $\mathrm{KKG}=$ koefisien keragaman genetik; $\sigma_{\sigma 2 \mathrm{~g}}=$ standar deviasi ragam genetik 
famili berdaya hasil tinggi. Kelemahan seleksi berdasarkan karakter tunggal yaitu terfokus pada satu karakter seleksi saja tanpa menghiraukan pengaruh dari berbagai karakter yang diamati. Kelemahan ini dapat ditutupi melalui seleksi berdasarkan beberapa karakter sekaligus. Penggunakan beberapa karakter seleksi dilakuakan berdasarkan nilai duga heritabilitas. Jika dilihat dari nilai heritabilitasnya yang tinggi menunjukkan bahwa faktor genetik dari tanaman lebih berpengaruh terhadap karakter tanaman daripada faktor lingkungannya (Wirawan et al., 2013). Perubahan nilai rataan populasi dasar famili $\mathrm{F} 3$, rataan genotipe terseleksi berdasarkan bobot biji per tanaman, dan rataan genotipe terseleksi berdasarkan jumlah anakan produktif, persentase floret hampa serta bobot biji per tanaman gandum untuk dataran tinggi terdapat pada Tabel 5. Berdasarkan bobot biji per tanaman dan seleksi multikarakter (jumlah anakan produktif, persentase floret hampa dan bobot biji per tanaman) pada lingkungan optimum, terseleksi 348 individu berdaya hasil tinggi yang diperoleh dari 39 famili. Keuntungan seleksi berdasarkan beberapa karakter sekaligus adalah penurunan persentase floret hampa dari genotipe yang terseleksi.

Tabel 5. Perubahan nilai rataan populasi dasar famili F3, rataan genotipe terseleksi berdasarkan bobot biji per tanaman, dan rataan genotipe terseleksi berdasarkan jumlah anakan produktif, persentase floret hampa, serta bobot biji per tanaman gandum untuk dataran tinggi

\begin{tabular}{lrrr}
\hline Karakter & $\overline{\mathrm{x}}_{\mathrm{D}}$ & $\overline{\mathrm{x}}_{\mathrm{BBT}}$ & $\overline{\mathrm{x}}_{\mathrm{M}}$ \\
\hline Tinggi tanaman (cm) & 67.8 & 69.3 & 69.4 \\
Jumlah anakan produktif & 5.4 & 7.4 & 7.8 \\
Panjang malai (cm) & 9.0 & 9.7 & 9.6 \\
Jumlah spiklet & 17.8 & 19.0 & 19.1 \\
Umur berbunga (HST) & 61.3 & 60.4 & 60.5 \\
Umur panen (HST) & 96.8 & 97.0 & 96.7 \\
Persentase floret hampa (\%) & 49.8 & 46.2 \\
Jumlah biji per malai & 67.1 & 28.4 & 30.7 \\
Bobot biji per malai (g) & 17.5 & 0.6 & 0.7 \\
Jumlah biji per tanaman & 0.4 & 267.4 & 262.8 \\
Bobot biji per tanaman (g) & 132.0 & 8.3 & 8.1 \\
\hline
\end{tabular}

Keterangan: $\bar{x}_{D}=$ rata-rata populasi dasar; $\bar{x}_{\mathrm{BBT}}=$ rata-rata genotipe terseleksi berdasarkan bobot biji per tanaman; $\overline{\mathrm{x}}_{\mathrm{M}}=$ rata-rata genotipe terseleksi berdasarkan jumlah anakan produktif, jumlah biji per malai, serta bobot biji per tanaman

\section{KESIMPULAN}

Hasil analisis ragam menunjukkan bahwa famili berbeda nyata pada karakter umur berbunga, umur panen, persentase floret hampa, jumlah biji per malai, bobot biji per malai, jumlah biji per tanaman, dan bobot biji per tanaman. Karakter tinggi tanaman dan umur berbunga merupakan karakter berbeda nyata di antara varietas pembanding. Karakter yang memiliki nilai heritabilitas tinggi yaitu karakter umur berbunga, umur panen, persentase floret hampa, jumlah biji per malai, bobot biji per malai, jumlah biji per tanaman, dan bobot biji per tanaman. Berdasarkan bobot biji per tanaman dan seleksi multikarakter (jumlah anakan produktif, persentase floret hampa, dan bobot biji per tanaman) pada lingkungan optimum, terpilih 80 individu terbaik (masing-masing 5 individu dari 20 famili).

\section{DAFTAR PUSTAKA}

Acquaah, G. 2007. Principle of plant genetic and breeding. Malden. Blackwell Publishing.
Balitsereal. 2011. Sumberdaya genetik. Highlight Balitsereal 1-15. http://balitsereal.litbang.deptan.go.id [15 Desember 2013].

Barmawi, M., A. Yushardi, N. Sa'diyah. 2013. Daya waris dan harapan kemajuan seleksi karakter agronomi kedelai generasi F2 hasil persilangan antara Yellow Bean dan Taichung. J. Agrotek Tropika 1:20-24.

Budiarti, S.G. 2005. Karakterisasi beberapa sifat kuantitatif plasma nutfah gandum (Triticum aestivum L.). Buletin Plasma Nutfah 11:49-54.

Mangi, S.A., M.A. Sial, B.A. Anshari, M.A. Arain. 2007. Study of genetic parameters in segregating populations of spiring wheat. Pak. J. Bot. 39:24072413.

Martono, B. 2009. Keragaman genetik, heritabilitas dan korelasi antar karakter kuantitatif nilam (Pogostemon sp. ) hasil fusi protoplasma. J. Littri 15:9-15. 
Natawijaya, A. 2012. Seleksi generasi awal segregan F2 gandum (Triticum aestivum L.) untuk perbaikan daya hasil. Tesis. Sekolah Pascasarjana. Institut Pertanian Bogor. Bogor.

Nur, A., Trikoesoemaningtyas, N. Khumaida, S. Yahya, 2012. Evaluasi dan keragaman genetik 12 galur gandum introduksi di lingkungan tropika basah. J. Agrivigor 11:230-243.

Prinaria, A., A. Baihaki, R. Setiamihardja, A.A. Daradjat. 1995. Variabilitas genetik dan heritabilitas karakterkarakter biomassa 53 genotipe kedelai. Zuriat 6:8892.

Setyowati, M., I. Hanarida, Sutoro, 2009. Pengelompokan plasma nutfah gandum (Triticum aestivum) berdasarkan karakter kuantitatif tanaman. Buletin Plasma Nutfah 15:32-37.

Suharsono, M. Jusuf. 2009. Analisis generasi F2 dan Seleksi pertama dari persilangan kedelai antara kultivar Slamet dan Wase. J. Agron. Indonesia 37:21-27.

Sungkono, Trikoesoemaningtyas, D. Wirnas, D. Sopandie, 2009. Pendugaan parameter genetik dan seleksi galur mutan sorgum (Sorghum bicolor (L.) Moench) di tanah masam. J. Agron. Indonesia 37:220-225.
Syukur, M., S. Sujiprihati, A. Siregar. 2010. Pendugaan parameter genetik beberapa karakter agronomi cabai F4 dan evaluasi daya hasilnya menggunakan rancangan perbesaran (augmented desaign). J. Agrotropika 15:9-16.

Syukur, M., S. Sujiprihati, R. Yunianti. 2012. Teknik Pemuliaan Tanaman. Penebar Swadaya. Jakarta.

Wahyu, Y., I. Darwati, Rosita, M.Y. Pulungan, I. Roostika. 20013. Keragaan mutan putatif purwoceng (Pimpinella pruatjan Molk.) dari benih diiradiasi sinar gamma pada tiga ketinggian tempat. J. Agron. Indonesia 41:77-82.

Wirawan, D., Rosmayati, L.A.P. Putri. 2013. Uji potensi produksi beberapa galur/varietas gandum (Triticum aestivum L.) di dataran tinggi Karo. Jurnal Online Agroekoteknologi 2:1-15.

Wirnas, D., I. Widodo, Sobir, Trikoesoemaningtyas, D. Sopandie. 2006. Pemilihan karakter agronomi untuk menyusun indeks seleksi pada 11 populasi kedelai generasi F6. Bul. Agron 34:19-24.

Yunianti, R., S. Sastrosumarjo, S. Sujiprihati, M.Surahman, S.H. Hidayat. 2010. Kriteria seleksi untuk perakitan varietas cabai tahan Phytophthora capsici Leonian. J. Agron. Indonesia 38:122-129. 